\title{
System Quality and Student's Acceptance of the E-learning System: The Serial Mediation of Perceived Usefulness and Intention to Use
}

\author{
Maha Ismail Alkhawaja \\ University Sultan Zainal Abidin, Malaysia \\ ORCID: 0000-0002-0862-354X \\ Mutia Sobihah Abd Halim \\ University Sultan Zainal Abidin, Malaysia \\ ORCID: 0000-0003-1614-9398 \\ Mohanad S. S. Abumandil \\ University Malaysia Kelantan, Malaysia \\ ORCID: 0000-0003-0121-306X \\ Ahmed Samed Al-Adwan \\ Al-Ahliyya Amman University, Jordan \\ ORCID: 0000-0001-5688-1503
}

Received: 30 Apr 2021

Accepted: 19 Oct 2021

\begin{abstract}
This study explores the mechanism through which system quality influences e-learning system acceptance. Precisely, this study aims to examine how perceived usefulness and intention to use serially mediate the impact of system quality on actual use. The data were collected from three public universities in Jordan. Structural equation modeling was employed to examine 336 questionnaires. The findings reveal that system quality significantly affects perceived usefulness and intention to use, perceived usefulness significantly affects intention to use and actual use, where the intention to use significantly affects actual use of the e-learning system as well. Furthermore, the study also confirms that system quality does not affect the e-learning system actual use directly but indirectly and serially through the two acceptance variables, perceived usefulness and intention to use. Thus, this study improves the understanding of student's acceptance and behavior towards the e-learning system in Jordan public universities and the effect of system quality attributes on this relationship. Also, this study set certain directions for the decision-makers and university management in designing their strategies.
\end{abstract}

Keywords: actual use, e-learning system, intention to use, perceived usefulness, serial mediators, system quality

\section{INTRODUCTION}

Academic institutions invest in e-learning system to derive several educational and non-educational benefits; for-instance, quick access to education, learner's flexibility to interact, greater self-efficacy, knowledge creation, and reduction in cost (Alkhawaja \& Abd Halim, 2019). E-learning systems are advanced internetbased applications that academic staff, students, and trainers use at educational institutions. Combining Information Communication Technology (ICT) with education resulted in e-learning system platforms implementation in higher education with positive impacts on educational goals in developing countries, such 
as increased student learning, effective management, and reduced cost (Alkhawaja \& Abd Halim, 2019; Bhuasiri et al., 2012; Hadullo et al., 2017; Kanwal \& Rehman, 2017; Mwakyusa \& Mwalyagile, 2016).

Despite the growing importance of e-learning systems, developing countries are struggling to offer successful e-learning systems. Among the announced e-learning projects in the developing context, only $15 \%$ were successful, $40 \%$ partially failed, and $45 \%$ failed (Almaiah et al., 2020). In Jordan, many public university students do not use e-learning systems and prefer traditional face-to-face interaction (Jaber, 2016; Kanwal \& Rehman, 2017), and this lack of usage could be a major reason for the e-learning system failure (Shah \& Attiq, 2016). However, the main reason behind the non-adoption of e-learning systems can be associated with technological problems (Al-araibi et al., 2019). Therefore, the determinants of students' level of acceptance of the e-learning system in developing countries should be explored. To fill the identified research gap, this study uses the Technology Acceptance Model (TAM) of Davis (1989) expanded by the DeLone \& McLean Information System Success Model (William \& Ephraim, 2003) to investigate how system quality influences the actual use of e-learning systems among Jordanian students through serial mediation of the acceptance variables; perceived usefulness and intention to use.

\section{LITERATURE REVIEW AND HYPOTHESES DEVELOPMENT}

\section{Information System Success Model (DL\&ML)}

Due to the inter-related, complex, and multi-dimensional structure of information systems, early attempts remained nascent in conceptualizing information system success. To manage inconsistencies, DeLone and McLean (1992) presented a success model that was later improved to address changes in the information system over time. The modified DL\&ML model comprises six elements: system quality, information quality, service quality, user satisfaction, intention to use, and outcomes. Users' positive experience with a system improves intention to use and satisfaction, which further influences the individual and organization level (DeLone \& McLean, 2003). Figure 1 shows an example of modified DL\&ML model.

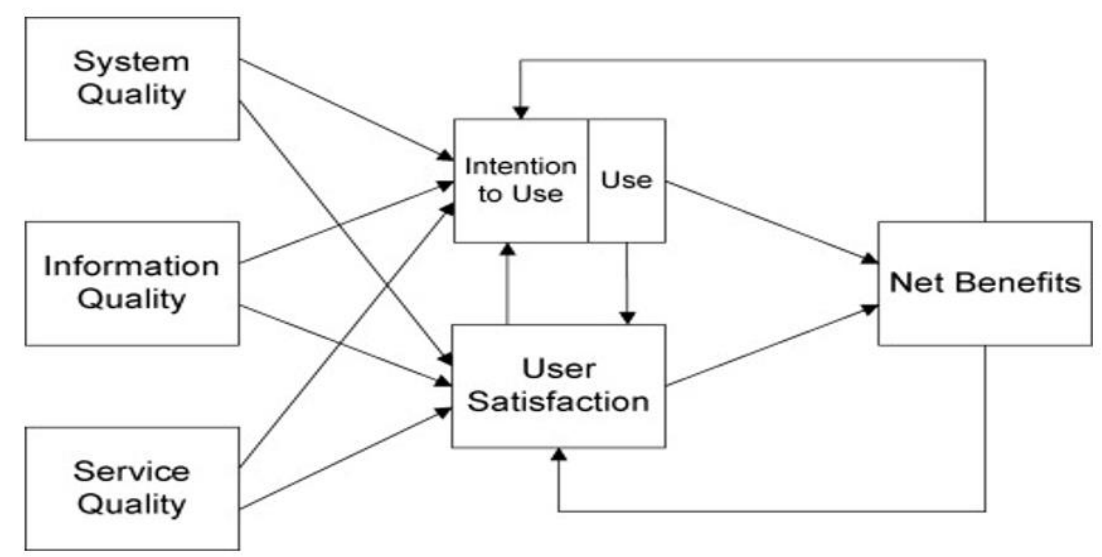

Figure 1. The updated IS success model (DeLone \& McLean, 2003)

\section{Technology Acceptance Model (TAM)}

The Technology Acceptance Model (TAM) (Bagozzi et al., 1992) is a common model behind explaining the acceptance of information systems. TAM outlines the procedural relationship between belief and behavior via attitude and intention, enabling an understanding of new technology adoption specially in the education field (Maphosa, 2021). This model helps explain the factors influencing behavioral intention to accept and adopt new technologies from end-users' perspectives (Chao, 2019). The model is an extension of Fishbein's theory of reasoned action (Fishbein, 1979). TAM posits that perceived usefulness and perceived ease of use drive individuals' attitudes toward their intention to use an information system, which may be converted into the actual use of the information system. Also, perceived usefulness may have a direct impact on perceived ease of use. Among the components of TAM, both perceived usefulness and perceived ease of use are the 
principal determinants that directly or indirectly explain the behavioral intention to accept new technologies (Lai, 2019). In the context of the information system, the D\&M model and TAM are the most popular models used to explain the adoption and success of information systems in education (Abdullah \& Ward, 2016; Almaiah, 2018; Almaiah et al., 2016, 2020). Figure 2 shows an example of TAM.

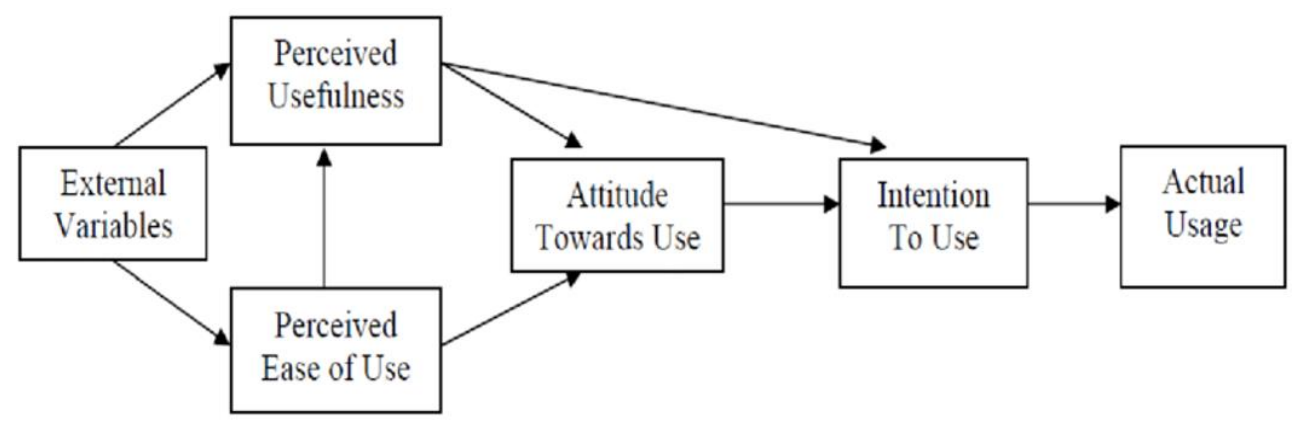

Figure 2. Technology Acceptance Model (TAM)

\section{The Effect of System Quality on Acceptance}

System quality is reflected through the functionalities of a system that are supposed to best address user needs with ease and minimal disruption (William \& Ephraim, 2003). System quality has been found to be a key determinant of the system's success and has a strong direct influence on perceived usefulness from students' perspective (Alshurideh et al., 2019; Calisir et al., 2014; Rui-Hsin \& Lin, 2018). For example, in a sample of 189 university students, Jaber (2016) found that $70 \%$ of the respondents mentioned that they prefer and would use beneficial e-learning systems that save effort and time and are available at any time with quick navigation tools. Accordingly, this study posits the following hypothesis:

H1 System quality in terms of adaptability, availability, reliability, usability, and response time has a significant effect on perceived usefulness.

Moreover, users are more likely to use an information system perceived as useful (Ma'arop \& Embi, 2016). Likewise, the value that students can gain from a system is a main element in assessing the students' intention to use the educational information system (Calisir et al., 2014; Davis, 1989; Fathema et al., 2015; Hariguna et al., 2017). Almaiah and Alismaiel (2019) illustrated that perceived usefulness is one of the most significant factors of users' intentions towards the usage of learning systems. Accordingly, the following hypothesis is posited:

H2 Perceived usefulness has a significant effect on the intention to use.

The TRA, which is the basis for TAM, posits that behavioral intentions are the most common predictors of human behaviors. Hence, an individual's intention to carry out a specific task is the instant predictor of actual behavior (Ajzen \& Fishbein, 1980). Behavioral intentions are derived through certain motivational factors, which are "indications of how hard people are planning to try and how much effort they are planning to exert to perform the behavior" (Ajzen, 1991, p. 181) In the e-learning context, Almaiah and Alyoussef (2019) confirmed the positive impact of intention to use on actual use. Hence, the following hypotheses are posited:

H3 Intention to use has a significant effect on actual use.

H4 Perceived usefulness and intention to use serially mediate the relationship between system quality and actual use.

Ghazal et al. (2017) revealed that system quality has a greater impact on user intention to use, and e-learning systems with technical issues and other difficulties may negatively impact user intention to use it. According to Costa et al. (2016), although system quality plays an important role in determining intention to use, usage depends on the features that a system offers. Therefore, the following hypothesis is posited. 
H5 System quality in terms of adaptability, availability, reliability, usability, and response time has a significant effect on the intention to use the e-learning system.

Almaiah and Alismaiel (2019) suggested that perceived usefulness is a crucial factor affecting the use of information systems, and users will use a system if they find it beneficial for their performance. Furthermore, prior research established the statistically positive impact of perceived usefulness on actual use (Alenazy et al., 2019; Algunto et al., 2017; Larmuseau et al., 2018). Thus, the following hypothesis is posited:

H6 Perceived usefulness has a significant effect on actual use.

Systems that are easy and available and have attractive features will encourage users to use the system more often (Mohammadi, 2015). Freeze et al. (2010), Zuama et al. (2017), and Aldholay et al. (2018) found a positive effect of system quality on e-learning system actual use, and supported the significant impact of system quality on students' actual use. Therefore, the following hypothesis is posited:

H7 System quality in terms of adaptability, availability, reliability, usability, and response time has a significant effect on actual use.

\section{RESEARCH METHODOLOGY}

\section{Instrument Development}

This study used a quantitative approach in which a survey was developed and adapted from several established work as shown in Table 1. Figure $\mathbf{3}$ shows the theoretical framework of our study. Items were rated on a ten-point interval scale from "Strongly Disagree" to "Strongly Agree." Three specialists who were $\mathrm{PhD}$ holders in information system, management, and management information science involved in the elearning field evaluated each question of the instrument, and appropriate changes were made. Using backto-back approach, the instrument was translated to the Arabic language as it is the respondent's native language. Also, distributing the survey in Arabic is expected to increase the understanding level, which make answering it easier and, accordingly, increase the response rate. The survey was proceeded with a cover letter and directions to fill the survey, Then, a pre-test was conducted on 50 students selected randomly from two public universities to enhance the instrument development based on student understanding (Alkhawaja et al., 2020). Finally, a pilot study was conducted on 150 students from three public universities and 120 response questionnaires were analyzed. Using IBM-SPSS version 24, data was checked and found to be normally distributed and free of outliers. Then, the reliability of items was tested. The five dimensions of system quality, perceived usefulness, intention to use, and actual use were found reliable with Cronbach's alpha $>0.7$ as illustrated in Table 1.

\section{Sampling and Data collection}

The population of the current study comprised all public university students in Jordan. According to the Ministry of Higher Education (MOHE), there are more than 209,000 students in 10 public universities in Jordan. Four public universities were selected using multi-stage cluster sampling, one from the north, two from the middle, and one from the south regions. The data were collected through a self-administrated survey by distributing 422 questionnaires among the students from February to April 2019. Of these, 369 questionnaires were returned, producing a response rate of $93 \%$. Of these, 336 questionnaires were suitable for analysis. The collected data was tested and found to be normally distributed and free of outliers. 
Table 1. Instrument development

\begin{tabular}{lllcc}
\hline Construct & Dimension & Source & $\begin{array}{c}\text { Number } \\
\text { of items }\end{array}$ & $\begin{array}{c}\text { Cronbach's } \\
\text { alpha }\end{array}$ \\
\hline System & Adaptability & (Amin et al., 2016; Liao \& Huang, 2009; Ren et al., 2017) & 6 & 0.914 \\
quality & Availability & (Al-Fraihat et al., 2020; Amin et al., 2016; Ren et al., 2017) & 5 & 0.844 \\
& Response Time & (Amin et al., 2016; Freeze et al., 2010; Ren et al., 2017) & 4 & 0.875 \\
& Reliability & (Ren et al., 2017; Udo et al., 2011) & 4 & 0.854 \\
& Usability & (Almaiah \& Al Mulhem, 2018; Koohang \& Paliszkiewicz, 2016) & 5 & 0.849 \\
\hline Perceived usefulness & (Almaiah \& Alismaiel, 2019; Ghazal et al., 2017; Wong, 2015) & 6 & 0.914 \\
\hline Intention to use & (Calisir et al., 2015; Mohammadi, 2015; Tsai et al., 2017) & 6 & 0.946 \\
\hline Actual use & (Bastola et al., 2019; Freeze et al., 2010; Mohammadi, 2015) & 6 & 0.958 \\
\hline
\end{tabular}

Of the respondents, 184 (55\%) were female, and 152 (45\%) were male. Concerning age, 122 (36\%) respondents were in the age of 18 to $22,153(46 \%)$ were in the age range of 23 to 26 , and $61(18 \%)$ were within the age group of 27 years and above. Furthermore, most respondents (50\%) had 8 to 10 years of internet experience, while $112(33 \%)$ respondents had 4 to 7 years of internet experience, and only $14(5 \%)$ students had 1 to 3 years of experience using the Internet.

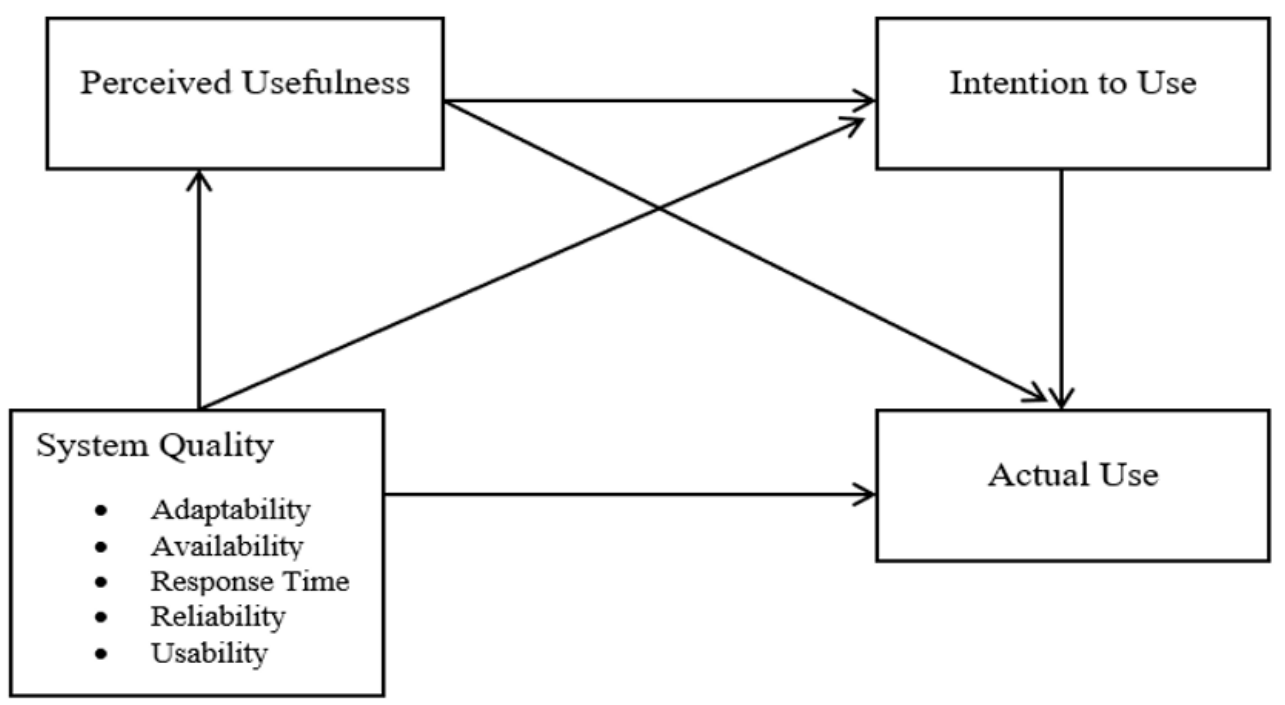

Figure 3. Theoretical framework

\section{Measurement Model}

Structural Equation Modeling (SEM) through AMOS 24 was employed to determine the construct validity and examine hypothesized paths. Confirmatory Factor Analysis (CFA) was conducted to assess the discriminant and convergent validity during the first stage. In this regard, the measurement model was developed. As illustrated in Table 2, the model fitness indices showed that the measurement model is fit with all fit indices falling under the recommend range i.e., $\mathrm{CFI}>0.90, \mathrm{TLI}>0.90, \chi 2 / \mathrm{df}<3, \mathrm{RMSEA}<0.08$ (Bagozzi \& Yi, 1988; Bollen \& Hoyle, 2012; Browne \& Cudeck, 1992; Hair et al., 2014). Bagozzi and Yi (1988) suggested that the convergent validity of the constructs will be satisfied if the value of composite reliability $(C R)>0.7$, standardized factor loadings $>0.5$ and average variance extracted (AVE) $>0.5$. System quality scored 0.973 $\mathrm{CR}$ and $0.878 \mathrm{AVE}$, perceived usefulness scored $0.948 \mathrm{CR}$ and $0.759 \mathrm{AVE}$, intention to use scored $0.940 \mathrm{CR}$ and 0.731 AVE and actual use scored 0.957 CR and 0.791 AVE. 
Table 2. Fitness indices for measurement model

\begin{tabular}{|c|c|c|c|c|c|}
\hline \multirow{2}{*}{ Fit indices } & \multicolumn{4}{|c|}{ Measurement model } & \multirow{2}{*}{ Cut off value } \\
\hline & System quality & Perceived usefulness & Intention to use & Actual use & \\
\hline$x^{2}$ & 554.639 & 24.911 & 26.750 & 26.801 & \\
\hline$p$ value & 000 & 002 & 002 & 002 & \\
\hline$x 2 / d f$ & 2.150 & 2.968 & 2.972 & 2.798 & $<3$ \\
\hline AGFI & .930 & .944 & .931 & .941 & $\geq .80$ \\
\hline TLI & .979 & .989 & .986 & .988 & $\geq .90$ \\
\hline CFI & .980 & .992 & .992 & .993 & $\geq .90$ \\
\hline IFI & .980 & .993 & .992 & .993 & $\geq .90$ \\
\hline RMSEA & .059 & .073 & .077 & .077 & $\leq .08$ \\
\hline
\end{tabular}

Using the Fornell and Larcker (1981) method, the discriminant validity was evaluated. Table 3 reveals that the value of the square root of AVE on the diagonal is larger than the corresponding correlation among the variables. So, discriminant validity is also satisfied.

Table 3. Discriminant validity

\begin{tabular}{lcccccc}
\hline & CR & AVE & ITU & SYSQ & PU & AU \\
\hline ITU & 0.940 & 0.731 & $\mathbf{0 . 8 5 5}$ & & & \\
SYSQ & 0.973 & 0.878 & 0.722 & $\mathbf{0 . 9 3 7}$ & & \\
PU & 0.948 & 0.759 & 0.805 & 0.689 & $\mathbf{0 . 8 7 1}$ & \\
AU & 0.957 & 0.791 & 0.609 & 0.480 & 0.649 & $\mathbf{0 . 8 8 9}$ \\
\hline
\end{tabular}

Note: Squared AVE are reported in the diagonal

\section{Structural Model and Hypotheses Testing}

After the assessment of the measurement model, a structural model was developed to examine the hypothesized paths. In this study, the second-order construct system quality was simplified and transformed into a first-order construct through an item-parceling procedure (Awang et al., 2015). Table 4 and Figure 4 shows that the model is fitted with all fit indices fall under the recommended range (Chisq/df $<3 ; \mathrm{CFI}>0.90$; TLI>0.90; RMSEA<.08) (Bagozzi \& Yi, 1988; Bollen \& Hoyle, 2012; Browne \& Cudeck, 1992; Hair et al., 2014).

Table 4. Fitness indices for structural model

\begin{tabular}{lcc}
\hline Fit indices & Structural model & Cut off value \\
\hline$\chi 2$ & 476.198 & \\
$\mathrm{p}$-value & 0.000 & $<3$ \\
$\chi 2 / \mathrm{df}$ & 2.126 & $\geq .80$ \\
$\mathrm{AGFI}$ & 0.869 & $\geq .90$ \\
TLI & 0.972 & $\geq .90$ \\
CFI & 0.975 & $\geq .90$ \\
IFI & 0.975 & $\leq .08$ \\
RMSEA & 0.058 & $\leq .08$ \\
SRMR & 0.0346 & \\
\hline
\end{tabular}

Table $\mathbf{4}$ presents the results of the hypotheses testing. $\mathbf{H} \mathbf{1}$ posited that system quality in terms of adaptability, availability, reliability, usability, and response time would significantly affect perceived usefulness. $\mathbf{H} \mathbf{1}$ was supported as the standardized $\beta$ value $(0.689)$ from system quality to users' perceived usefulness was significant with $p<0.05$. $\mathbf{H 2}$ posited that perceived usefulness would have a significant impact on students' intention to use. $\mathbf{H} \mathbf{2}$ was also supported as the standardized $\beta$ value $(0.585)$ from perceived usefulness to users' intention to use is significant with $p<0.05$. H3 posited that students' intention to use would have a significant effect on actual use. Table $\mathbf{4}$ shows that $\mathbf{H} \mathbf{3}$ is supported because the standardized $\beta$ value (0.254) from users' intention to use to actual use was significant with $p<0.05$. $\mathbf{H 5}$ posited that system quality in terms of adaptability, availability, reliability, usability, and response time would significantly affect students' intention to use the e-learning system. $\mathbf{H} \mathbf{5}$ is supported as the standardized $\beta$ value (0.319) from system quality to users' intention to use is significant with $p<0.05$. $\mathbf{H 6}$ posited that students' perceived usefulness 
would have a positive impact on actual use. H5 was supported as the standardized $\beta$ value (0.456) from perceived usefulness to actual use was significant with $p<0.05$. H7 posited that system quality would have a direct effect on students' actual use of e-learning systems. As Table $\mathbf{5}$ shows, $\mathbf{H} \mathbf{7}$ was not supported as the standardized $\beta$ value $(-0.017)$ from system quality to actual use is insignificant with a $p$-value greater than 0.05. Table 4 shows the results of the hypothesis testing, and Figure 4 illustrates the structural model.

Table 5. Results of hypotheses testing

\begin{tabular}{lllllc}
\hline & & & Estimate & S.E. & p-value \\
\hline PU & $\leftarrow$ & SYSQ & .689 & .047 & $* * *$ \\
ITU & $\leftarrow$ & PU & .585 & .049 & $* * *$ \\
ITU & $\leftarrow$ & SYSQ & .319 & .048 & $* * *$ \\
AU & $\leftarrow$ & ITU & .254 & .084 & .002 \\
AU & $\leftarrow$ & PU & .456 & .081 & $* * *$ \\
AU & $\leftarrow$ & SYSQ & .017 & .069 & .794 \\
\hline
\end{tabular}

\section{Testing of Serial Mediation (H4)}

As SEM programs, like AMOS, offer greater flexibility and model specification and estimation options, the indirect effect, and total effect will be calculated simultaneously using AMOS software, and the specific indirect effect for each mediator will be calculated using AMOS user-defined estimands (Amos Development Corporation, 2013). Additionally, Preacher and Hayes (2008) recommended performing the resampling method of bootstrapping (Bollen \& Stine, 1990). In this technique, the indirect effect is considered statistically significant if its confidence interval (upper and lower) does not contain zero or a $p$-value less than 0.05 in statistical programs (Hayes, 2012; Pieters, 2017). The bootstrapping method was performed using AMOS with 1000 bootstraps and 95\% confidence intervals. The result of bootstrapping can be reported to demonstrate the presence of a mediation relationship in a model by proving the significance of the indirect effects (Hayes, 2009).

The results in Table 6 demonstrate that the indirect effect through both mediators serially is significant. Additionally, the total indirect effect of the serial mediators in the link between system quality and actual use was confirmed to be significant. Hence, $\mathbf{H} \mathbf{4}$ is well supported.

Table 6. Bootstrapping results of mediating hypotheses

\begin{tabular}{lcccccc}
\hline Path & Estimate & S.E. & Lower & Upper & p-value & \\
\hline SYS-PU-AU & .102 & .045 & .023 & .208 & .004 & Significant \\
SYS-ITU-AU & .049 & .031 & .008 & .137 & .015 & Significant \\
SYS-PU-ITU-AU & .177 & .053 & .033 & .279 & .002 & Significant \\
Total Effect & .204 & .097 & .008 & .394 & .042 & Significant \\
\hline
\end{tabular}

\section{CONCLUSIONS AND DISCUSSION}

In the last decade, information systems have revolutionized the learning environment of educational institutions. This is very true in developed countries. However, in developing countries, e-learning systems are taking time to be accepted by users. Drawing on the TAM and D\&M model framework, the current study examined how perceived usefulness and intention to use serially mediate the impact of system quality on actual use. Results showed that system quality is significantly linked with perceived usefulness. This finding supports previous studies (Alshurideh et al., 2019; Cheng, 2012; Hariguna et al., 2017). This result indicates that e-learning systems with a high level of quality will be perceived as a useful system by students. 


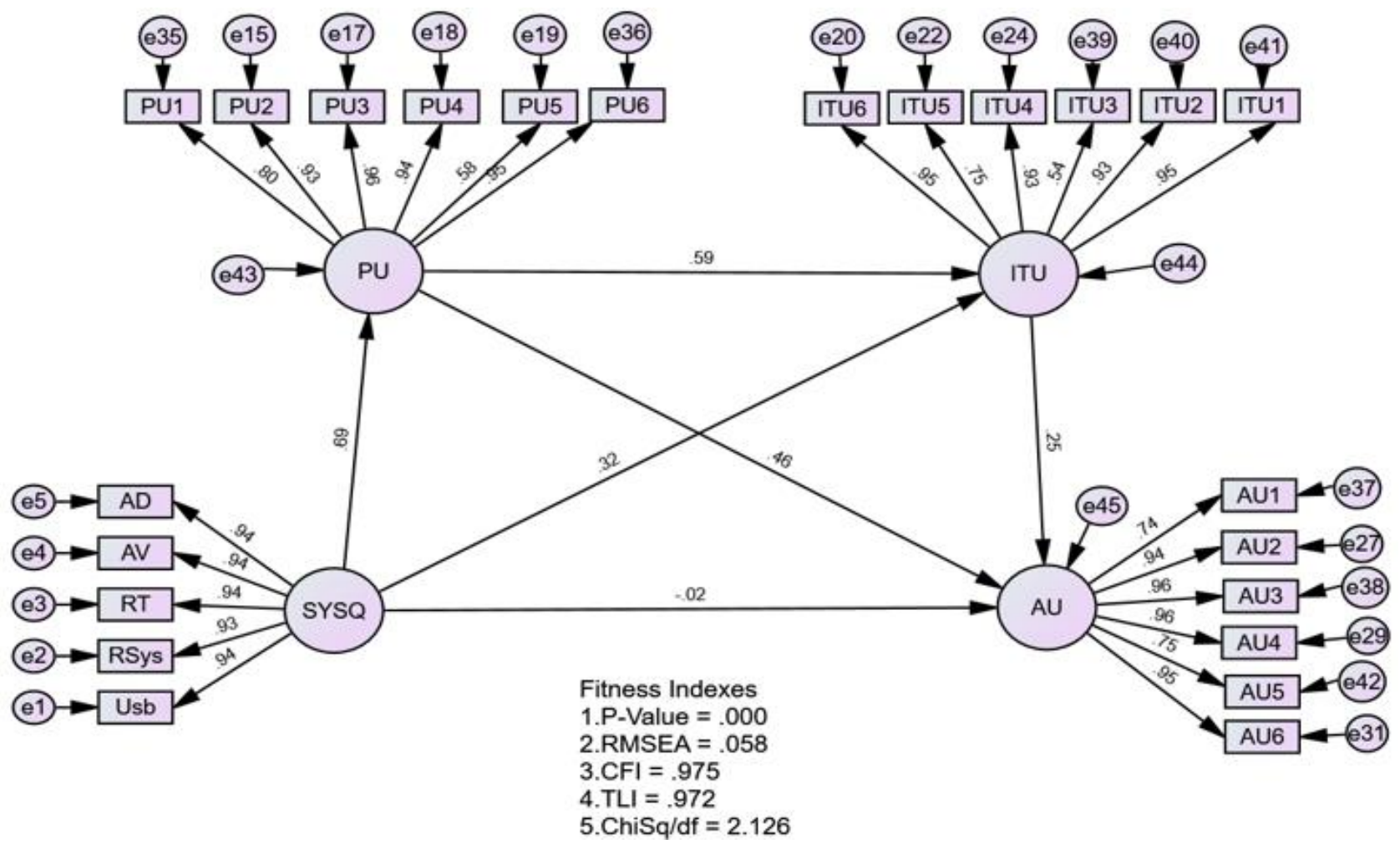

Figure 4. Structured model

This study found that perceived usefulness was significantly and positively linked with users' intention to use, supporting many studies (Alshurideh et al., 2019; Calisir et al., 2014; Davis, 1989; Fathema et al., 2015). This finding indicates that when students perceive the e-learning system as useful, they will develop their intentions towards using or keep using the e-learning system.

In addition, this study reveals a positive association between users' intention to use and actual use, which supports prior studies (Salloum et al., 2019; Sharma, 2019). However, the direct effect of system quality on actual use was insignificant. This result might be related to student's expertise level in using information systems in general and the e-learning system specifically, where students with more experience will tend to overcome the difficulties in using a system (Freeze et al., 2010). Another reason might be related to the freedom of use; if the usage of the e-learning system is compulsory, students will be forced to use an elearning system regardless of its low quality (Yakubu \& Dasuki, 2018). Another possible reason that students in Jordan Universities use the e-learning system to reach studying materials not to use activities, which leads the students to be forced to use the e-learning system to get the materials regardless of the system quality or the difficulties that they might face (Hijazi et al., 2020).

These direct causation relations resulted in an indirect effect of system quality on student's actual use. Consequently, both mediators serially and significantly mediated the effect of system quality on actual use. This finding supports the theoretical rationale of TAM, where user's behaviors can be predicted from the number of benefits they gain from using an information system; if the information system is useful for their performance, users develop their intentions to use the information system, which leads to final behavior, the actual use (Davis, 1989; Venkatesh et al., 2000).

This study concludes that system quality does not directly affect students' actual use of the e-learning system. Instead, students' actual behavior towards using the e-learning system in Jordan public universities is related to a series of psychological actions that result in actual use. The level of system quality offered by the elearning system in public universities affects the student's actual use indirectly, where system quality is linked with student's level of usefulness that they gain from using the e-learning system, which is linked with their positive intentions to use these systems, which finally leads to their decision actually to use the e-learning system. 
Understanding the mechanism of acceptance is vital for universities as student's acceptance and usage is the anchor of the system success. Students are the most important stakeholders that interact with the system and can determine the system difficulties, defects and errors. Decision makers in universities are advised to pay extra attention to the factors that affect student's acceptance and actual use of the e-learning system to ensure the success of implementation.

\section{LIMITATIONS AND FUTURE RESEARCH DIRECTIONS}

The current study has certain limitations. First, this study is cross-sectional. Therefore, future study is required to examine the influence of e-learning systems on actual use over a certain period, as e-learning systems need time to get familiar with a particular context. Second, this study employed a cross sectional method through distributing surveys to collect information due to time and cost restraints. Future study is recommended to experiment to assess the effectiveness of e-learning system through interviews to explore more in-depth factors behind the actual use. Future studies can incorporate service quality and information to provide a more comprehensive understanding of the factors affecting the actual use.

Author contributions: All authors were involved in concept, design, collection of data, interpretation, writing, and critically revising the article. All authors approve final version of the article.

Funding: The authors received no financial support for the research and/or authorship of this article.

Declaration of interest: Authors declare no competing interest.

Data availability: Data generated or analysed during this study are available from the authors on request.

\section{REFERENCES}

Abdullah, F., \& Ward, R. (2016). Developing a General Extended Technology Acceptance Model for E-Learning (GETAMEL) by analysing commonly used external factors. Computers in Human Behavior, 56, 238-256. https://doi.org/10.1016/j.chb.2015.11.036

Ajzen, I. (1991). The theory of planned behavior. Organizational Behavior and Human Decision Processes, 50(2), 179-211. https://doi.org/10.1016/0749-5978(91)90020-T

Ajzen, I., \& Fishbein, M. (1980). Understanding attitudes and predicting social behavior. Prentice-Hall.

Al-araibi, A. A. M., Mahrin, M. N. B., \& Yusoff, R. C. M. (2019). Technological aspect factors of e-learning readiness in higher education institutions: Delphi technique. Education and Information Technologies, 24(1), 567-590. https://doi.org/10.1007/s10639-018-9780-9

Alenazy, W. M., Al-Rahmi, W. M., \& Khan, M. S. (2019). Validation of TAM model on social media use for collaborative learning to enhance collaborative authoring. IEEE Access, 7, 71550-71562. https://doi.org/10.1109/ACCESS.2019.2920242

Al-Fraihat, D., Joy, M., \& Sinclair, J. (2020). Evaluating e-learning systems success: An empirical study. Computers in Human Behavior, 102, 67-86. https://doi.org/10.1016/j.chb.2019.08.004

Algunto, A. D. K., Jaryono, \& Daryono. (2017). Technology of e-government acceptance analysis on electronic resident identification card (E-KTP) adoption. Performance: Business \& Management Journal, 23(2), 77-88. https://doi.org/10.20884/1.performance.2016.23.2.272

Alhabeeb, A., \& Rowley, J. (2017). Critical success factors for eLearning in Saudi Arabian universities. International Journal of Educational Management, 31(2), 131-147. https://doi.org/10.1108/IJEM-012016-0006

Alharbi, H., \& Sandhu, K. (2019). New empirical data findings for student experiences of e-learning analytics recommender systems and their impact on system adoption. International Journal of Innovation in the Digital Economy (IJIDE), 10(2), 54-63. https://doi.org/10.4018/IJIDE.2019040104 
Alharthi, A., Alassafi, M. O., Walters, R. J., \& Wills, G. B. (2017). An exploratory study for investigating the critical success factors for cloud migration in the Saudi Arabian higher education context. Telematics and Informatics, 34(2), 664-678. https://doi.org/10.1016/j.tele.2016.10.008

Alkhawaja, M. I., \& Abd Halim, M. S. B. (2019). Challenges of e-learning system adoption in Jordan higher education. International Journal of Academic Research in Business and Social Sciences, 9(9), 487-494. https://doi.org/10.6007/IJARBSS/v9-i9/6317

Alkhawaja, M. I., Sobihah, M., \& Awang, Z. (2020). Exploring and developing an instrument for measuring system quality construct in the context of e-learning. International Journal of Academic Research in Business and Social Sciences, 403-413. https://doi.org/10.6007/JJARBSS/v10-i11/7953

Alla, M., Faryadi, Q., \& Fabil, N. B. (2015). The impact of system quality in e-learning system. International Journal of Computer Science and Electronics Engineering, 3(1), 37-42.

Almaiah, M. A. (2018). Acceptance and usage of a mobile information system services in University of Jordan. Education and Information Technologies, 23(5), 1873-1895. https://doi.org/10.1007/s10639-0189694-6

Almaiah, M. A., \& Al Mulhem, A. (2019). Analysis of the essential factors affecting of intention to use of mobile learning applications: A comparison between universities adopters and non-adopters. Education and Information Technologies, 24(2), 1433-1468. https://doi.org/10.1007/s10639-018-9840-1

Almaiah, M. A., \& Alismaiel, O. A. (2019). Examination of factors influencing the use of mobile learning system: An empirical study. Education and Information Technologies, 24(1), 885-909. https://doi.org/10.1007/s10639-018-9810-7

Almaiah, M. A., \& Alyoussef, I. Y. (2019). Analysis of the effect of course design, course content support, course assessment and instructor characteristics on the actual use of E-learning system. IEEE Access, 7, 171907-171922. https://doi.org/10.1109/ACCESS.2019.2956349

Almaiah, M. A., Al-Khasawneh, A., \& Althunibat, A. (2020). Exploring the critical challenges and factors influencing the e-learning system usage during COVID-19 pandemic. Education and Information Technologies, 25, 5261-5280. https://doi.org/10.1007/s10639-020-10219-y

Almaiah, M. A., Jalil, M. A., \& Man, M. (2016). Extending the TAM to examine the effects of quality features on mobile learning acceptance. Journal of Computers in Education, 3(4), 453-485. https://doi.org/10.1007/s40692-016-0074-1

Almarabeh, T. (2014). Students' perceptions of e-learning at the University of Jordan. International Journal of Emerging Technologies in Learning, 9(3), 31-35. https://doi.org/10.3991/ijet.v9i3.3347

Al-Rahmi, W. M., Yahaya, N., Aldraiweesh, A. A., Alamri, M. M., Aljarboa, N. A., Alturki, U., \& Aljeraiwi, A. A. (2019). Integrating technology acceptance model with innovation diffusion theory: An empirical investigation on students' intention to use e-learning systems. IEEE Access, 7, 26797-26809. https://doi.org/10.1109/ACCESS.2019.2899368

Alshurideh, M., Salloum, S. A., Al Kurdi, B., Monem, A. A., \& Shaalan, K. (2019). Understanding the quality determinants that influence the intention to use the mobile learning platforms: A practical study. International Journal of Interactive Mobile Technologies, 13(11), 157-183. https://doi.org/10.3991/ijim.v13i11.10300

Ameen, A., Alfalasi, K., Gazem, N. A., \& Isaac, O. (2019). Impact of system quality, information quality, and service quality on actual usage of smart government. Presented at the 2019 First International Conference of Intelligent Computing and Engineering (ICOICE). Hadhramout University, Mukalla, Yemen, December 15-16. 
Amin, M., Akter, A., \& Azhar, A. (2016). Factors affecting private university students' intention to adopt elearning system in Bangladesh. DIU Journal of Business and Economics, 10(2), 10-25. http://dspace.library.daffodilvarsity.edu.bd:8080/xmlui/handle/123456789/1549

Bagozzi, R. P., \& Yi, Y. (1988). On the evaluation of structural equation models. Journal of the Academy of Marketing Science, 16(1), 74-94. https://doi.org/10.1007/BF02723327

Bagozzi, R. P., Davis, F. D., \& Warshaw, P. R. (1992). Development and test of a theory of technological learning and usage. Human Relations, 45(7), 659-686. https://doi.org/10.1177/001872679204500702

Baron, R. M., \& Kenny, D. A. (1986). The moderator-mediator variable distinction in social psychological research: conceptual, strategic, and statistical considerations. Journal of Personality and Social Psychology, 51(6), 1173-1182. https://doi.org/10.1037/0022-3514.51.6.1173

Bhuasiri, W., Xaymoungkhoun, O., Zo, H., Rho, J. J., \& Ciganek, A. P. (2012). Critical success factors for elearning in developing countries: A comparative analysis between ICT experts and faculty. Computers \& Education, 58(2), 843-855. https://doi.org/10.1016/j.compedu.2011.10.010

Bollen, K. A., \& Hoyle, R. H. (2012). Latent variables in structural equation modeling. In R. H. Hoyle (Ed.), Handbook of structural equation modeling (pp. 56-67). The Guilford Press.

Bollen, K. A., \& Stine, R. (1990). Direct and indirect effects: Classical and bootstrap estimates of variability. Sociological Methodology, 20, 115-140. https://doi.org/10.2307/271084

Bouchrika, I. (2020). 51 LMS Statistics: 2019/2020 Data, trends \& predictions. Guide2Research. https://www.guide2research.com/research/Ims-statistics

Browne, M. W., \& Cudeck, R. (1992). Alternative ways of assessing model fit. Sociological Methods \& Research, 21(2), 230-258. https://doi.org/10.1177/0049124192021002005

Butler, B. S., \& Gray, P. H. (2006). Reliability, mindfulness, and information systems. MIS Quarterly, 30(2), 211-224. https://doi.org/10.2307/25148728

Calisir, F., Altin Gumussoy, C., Bayraktaroglu, A. E., \& Karaali, D. (2014). Predicting the intention to use a webbased learning system: Perceived content quality, anxiety, perceived system quality, image, and the technology acceptance model. Human Factors and Ergonomics in Manufacturing \& Service Industries, 24(5), 515-531. https://doi.org/10.1002/hfm.20548

Chao, C.-M. (2019). Factors determining the behavioral intention to use mobile learning: An application and extension of the UTAUT model. Frontiers in Psychology, 10, 1652. https://doi.org/10.3389/fpsyg.2019.01652

Cheng, Y.-M. (2012). The effects of information systems quality on nurses' acceptance of the electronic learning system. Journal of Nursing Research, 20(1), 19-31. https://doi.org/10.1097/JNR.0b013e31824777aa

Cheng, Y.-M. (2014). Roles of interactivity and usage experience in e-learning acceptance: A longitudinal study. International Journal of Web Information Systems, 10(1), 2-23. https://doi.org/10.1108/IJWIS05-2013-0015

Cidral, W. A., Oliveira, T., Di Felice, M., \& Aparicio, M. (2018). E-learning success determinants: Brazilian empirical study. Computers \& Education, 122, 273-290. https://doi.org/10.1016/j.compedu.2017.12.001

Costa, C. J., Ferreira, E., Bento, F., \& Aparicio, M. (2016). Enterprise resource planning adoption and satisfaction determinants. Computers in Human Behavior, 63, 659-671. https://doi.org/10.1016/j.chb.2016.05.090 
Dahlstrom, E., Brooks, D. C., \& Bichsel, J. (2014). The current ecosystem of learning management systems in higher education: Student, faculty, and IT perspectives: Research report. EDUCAUSE. https://library.educause.edu/-/media/files/library/2014/9/ers1414-pdf.pdf

Davcik, S. N. (2014). The use and misuse of structural equation modeling in management research: A review and critique. Journal of Advances in Management Research, 11(1), 47-81. https://doi.org/10.1108/JAMR-07-2013-0043

Davis, F. D. (1989). Perceived usefulness, perceived ease of use, and user acceptance of information technology. MIS Quarterly, 13(3), 319-340. https://doi.org/10.2307/249008

DeLone, W. H., \& McLean, E. R. (1992). Information systems success: The quest for the dependent variable. Information Systems Research, 3(1), 60-95. https://doi.org/10.1287/isre.3.1.60

Dreheeb, A. E., Basir, N., \& Fabil, N. (2016). Impact of system quality on users' satisfaction in continuation of the use of e-learning system. International Journal of e-Education, e-Business, e-Management and eLearning, 6(1), 13-20. https://doi.org/10.17706/ijeeee.2016.6.1.13-20

Fathema, N., Shannon, D., \& Ross, M. (2015). Expanding the Technology Acceptance Model (TAM) to examine faculty use of Learning Management Systems (LMSs) in higher education institutions. MERLOT Journal of Online Learning \& Teaching, 11(2), 210-232.

Fishbein, M. (1979). A theory of reasoned action: Some applications and implications. Nebraska Symposium on Motivation, 27, 65-116.

Fornell, C., \& Larcker, D. F. (1981). Evaluating structural equation models with unobservable variables and measurement error. Journal of Marketing Research, 18(1), 39-50. https://doi.org/10.1177/002224378101800104

Freeze, R. D., Alshare, K. A., Lane, P. L., \& Wen, H. J. (2010). IS success model in e-learning context based on students' perceptions. Journal of Information Systems Education, 21(2), 173-184. https://aisel.aisnet.org/jise/vol21/iss2/4

Ghazal, S., Aldowah, H., \& Umar, I. (2017). Critical factors to learning management system acceptance and satisfaction in a blended learning environment. In F. Saeed, N. Gazem, S. Patnaik, A. Saed Balaid, \& F. Mohammed (Eds.), Recent trends in information and communication technology. IRICT 2017. Lecture notes on data engineering and communications technologies (vol 5, pp. 688-698). Springer, Cham. https://doi.org/10.1007/978-3-319-59427-9_71

Hadullo, K., Oboko, R., \& Omwenga, E. (2017). A model for evaluating e-learning systems quality in higher education in developing countries. International Journal of Education and Development using ICT, 13(2), 185-204. https://www.learntechlib.org/p/180643/

Hair, J. F., Gabriel, M., \& Patel, V. (2014). AMOS covariance-based structural equation modeling (CB-SEM): Guidelines on its application as a marketing research tool. Brazilian Journal of Marketing, 13(2), 44-55. https://doi.org/10.5585/remark.v13i2.2718

Hariguna, T., Lai, M.-T., Hung, C.-W., \& Chen, S.-C. (2017). Understanding information system quality on public e-government service intention: An empirical study. International Journal of Innovation and Sustainable Development, 11(2-3), 271-290. https://doi.org/10.1504/IJISD.2017.083290

Harrati, N., Bouchrika, I., Tari, A., \& Ladjailia, A. (2016). Exploring user satisfaction for e-learning systems via usage-based metrics and system usability scale analysis. Computers in Human Behavior, 61, 463-471. https://doi.org/10.1016/j.chb. 2016.03.051

Hayes, A. F. (2009). Beyond Baron and Kenny: Statistical mediation analysis in the new millennium. Communication Monographs, 76(4), 408-420. https://doi.org/10.1080/03637750903310360 
Hayes, A. F. (2012). PROCESS: A versatile computational tool for observed variable mediation, moderation, and conditional process modeling [White paper]. http://www.afhayes.com/public/process2012.pdf

Hayes, A. F., \& Preacher, K. J. (2014). Statistical mediation analysis with a multicategorical independent variable. British Journal of Mathematical and Statistical Psychology, 67(3), 451-470. https://doi.org/10.1111/bmsp.12028

Islam, A. (2012). The role of perceived system quality as educators' motivation to continue e-learning system use. AIS Transactions on Human-Computer Interaction, 4(1), 25-43. https://aisel.aisnet.org/thci/vol4/iss1/2

Islam, A. (2016). E-learning system use and its outcomes: Moderating role of perceived compatibility. Telematics and Informatics, 33(1), 48-55. https://doi.org/10.1016/j.tele.2015.06.010

Jaber, O. A. (2016). An examination of variables influencing the acceptance and usage of E-learning systems in Jordanian higher education institutions [PhD dissertation, Cardiff Metropolitan University]. https://repository.cardiffmet.ac.uk/bitstream/handle/10369/7995/Omar\%20Jaber\%20PHD\%20Final \%20To\%20Submit\%20-\%20July\%202016\%20-\%20FINAL\%20-\%20PDF.pdf?sequence=1\&isAllowed=y

Kanwal, F., \& Rehman, M. (2017). Factors affecting e-learning adoption in developing countries-empirical evidence from Pakistan's higher education sector. IEEE Access, 5, 10968-10978. https://doi.org/10.1109/ACCESS.2017.2714379

Khasawneh, M., \& Yaseen, A. B. (2017). Critical success factors for e-learning satisfaction, Jordanian Universities' experience. Journal of Business \& Management, 5(1), 56-69. https://doi.org/10.25255/jbm.2017.5.1.56.69

Khawaldeh, F. (2017). The effectiveness of applying the Baldrige Quality Standards in higher education to achieve competitive advantage: Case study on Jordanian private universities. International Journal of Business and Management, 12(11), 233-248. https://doi.org/10.5539/ijbm.v12n11p218

Kiron, D., Prentice, P. K., \& Ferguson, R. B. (2014). The analytics mandate. MIT Sloan Management Review, 55(4), 1-25.

Koohang, A., \& Paliszkiewicz, J. (2016). E-learning courseware usability: Building a theoretical model. Journal of Computer Information Systems, 56(1), 55-61. https://doi.org/10.1080/08874417.2015.11645801

Lai, Y. H. (2019). The application of meta-analytic SEM on exploring factors that influence teachers' usage of interactive whiteboard. Pedagogical Research, 4(3), em0038. https://doi.org/10.29333/pr/5854

Larmuseau, C., Evens, M., Elen, J., Van Den Noortgate, W., Desmet, P., \& Depaepe, F. (2018). The relationship between acceptance, actual use of a virtual learning environment and performance: An ecological approach. Journal of Computers in Education, 5(1), 95-111. https://doi.org/10.1007/s40692-018-00989

Liao, C.-H., \& Huang, W.-L. (2009). Community adaptability, computer and internet self-efficacy, and intention of blended e-learning. International Journal of Society Systems Science, 1(3), 209-226. https://doi.org/10.1504/ijsss.2009.022816

Ma'arop, A. H., \& Embi, M. A. (2016). Implementation of blended learning in higher learning institutions: A review of the literature. International Education Studies, 9(3), 41-52, EJ1093338. https://doi.org/10.5539/ies.v9n3p41

Maphosa, V. (2021). Teachers' perspectives on remote-based teaching and learning in the COVID-19 era: Rethinking technology availability and suitability in Zimbabwe. European Journal of Interactive Multimedia and Education, 2(1), e02105. https://doi.org/10.30935/ejimed/9684 
Mohammadi, H. (2015). Investigating users' perspectives on e-learning: An integration of TAM and IS success model. Computers in Human Behavior, 45, 359-374. https://doi.org/10.1016/j.chb.2014.07.044

Mwakyusa, W. P., \& Mwalyagile, N. V. (2016). Impediments of e-learning adoption in higher learning institutions of Tanzania: An empirical review. Journal of Education and Practice, 7(30), 152-160. EJ1118921.

Noh, M. J., \& Lee, K. T. (2016). An analysis of the relationship between quality and user acceptance in smartphone apps. Information Systems and e-Business Management, 14(2), 273-291. https://doi.org/10.1007/s10257-015-0283-6

Pham, L., Limbu, Y. B., Bui, T. K., Nguyen, H. T., \& Pham, H. T. (2019). Does e-learning service quality influence e-learning student satisfaction and loyalty? Evidence from Vietnam. International Journal of Educational Technology in Higher Education, 16(1), 1-26. https://doi.org/10.1186/s41239-019-0136-3

Pieters, R. (2017). Meaningful mediation analysis: Plausible causal inference and informative communication. Journal of Consumer Research, 44(3), 692-716. https://doi.org/10.1093/jcr/ucx081

Preacher, K. J., \& Hayes, A. F. (2008). Asymptotic and resampling strategies for assessing and comparing indirect effects in multiple mediator models. Behavior Research Methods, 40(3), 879-891. https://doi.org/10.3758/BRM.40.3.879

Ren, J.-F., Fosso Wamba, S., Akter, S., Dubey, R., \& Childe, S. J. (2017). Modelling quality dynamics on business value and firm performance in big data analytics environment. International Journal of Production Research, 55(17), 5011-5026. https://doi.org/10.1080/00207543.2016.1154209

Rui-Hsin, K., \& Lin, C.-T. (2018). The usage intention of e-learning for police education and training. Policing: An International Journal, 41(1), 98-112. https://doi.org/10.1108/PIJPSM-10-2016-0157

Salloum, S. A., Al-Emran, M., Shaalan, K., \& Tarhini, A. (2019). Factors affecting the e-learning acceptance: A case study from UAE. Education and Information Technologies, 24(1), 509-530. https://doi.org/10.1007/s10639-018-9786-3

Sarrab, M., Elbasir, M., \& Alnaeli, S. (2016). Towards a quality model of technical aspects for mobile learning services: An empirical investigation. Computers in Human Behavior, 55(A), 100-112. https://doi.org/10.1016/j.chb.2015.09.003

Sharma, S. K. (2019). Integrating cognitive antecedents into TAM to explain mobile banking behavioral intention: A SEM-neural network modeling. Information Systems Frontiers, 21(4), 815-827. https://doi.org/10.1007/s10796-017-9775-x

Stoyanov, S., \& Kirchner, P. (2004). Expert concept mapping method for defining the characteristics of adaptive e-learning: ALFANET project case. Educational Technology Research and Development, 52(2), 41-54. https://doi.org/10.1007/BF02504838

Tarhini, A., Masa'deh, R., Al-Busaidi Kamla, A., Mohammed Ashraf, B., \& Maqableh, M. (2017). Factors influencing students' adoption of e-learning: A structural equation modeling approach. Journal of International Education in Business, 10(2), 164-182. https://doi.org/10.1108/JIEB-09-2016-0032

Udo, G. J., Bagchi, K. K., \& Kirs, P. J. (2011). Using SERVQUAL to assess the quality of e-learning experience. Computers in Human Behavior, 27(3), 1272-1283. https://doi.org/10.1016/j.chb.2011.01.009

Venkatesh, V., Morris, M. G., \& Ackerman, P. L. (2000). A longitudinal field investigation of gender differences in individual technology adoption decision-making processes. Organizational Behavior and Human Decision Processes, 83(1), 33-60. https://doi.org/10.1006/obhd.2000.2896 
William, H. D., \& Ephraim, R. M. (2003). The DeLone and McLean model of information systems success: A ten-year update. Journal of management information systems, 19(4), 9-30. https://doi.org/10.1080/07421222.2003.11045748

Wong, G. K. (2015). Understanding technology acceptance in pre-service teachers of primary mathematics in Hong Kong. Australasian Journal of Educational Technology, 31(6), 713-735, https://doi.org/10.14742/ajet.1890

Yakubu, M. N., \& Dasuki, S. (2018). Assessing elearning systems success in Nigeria: An application of the DeLone and McLean information systems success model. Journal of Information Technology Education: Research, 17, 183-203. https://doi.org/10.28945/4077

Zuama, R. A., Hudin, J. M., Puspitasari, D., Hermaliani, E. H., \& Riana, D. (2017, August 8-10). Quality dimensions of DeLone-McLean model to measure students' accounting computer satisfaction: An empirical test on accounting system information. In 2017 5th International Conference on Cyber and IT Service Management (CITSM), 2017, (pp. 1-6), Denpasar, Indonesia. https://doi.org/10.1109/CITSM. 2017.8089318

Correspondence: Maha Ismail Alkhawaja, University Sultan Zainal Abidin, Malaysia.

E-mail: memkhawajah@yahoo.com 